\title{
Gene variations in oestrogen pathways, CYP19A1, daily $17 \beta$-estradiol and mammographic density phenotypes in premenopausal women
}

Vidar G Flote ${ }^{1 *}$, Anne-Sofie Furberg ${ }^{2}$, Anne McTiernan ${ }^{3}$, Hanne Frydenberg ${ }^{1}$, Giske Ursin ${ }^{4}$, Anita Iversen ${ }^{5}$, Trygve Lofteroed ${ }^{1}$, Peter T Ellison ${ }^{6}$, Erik A Wist', Thore Egeland ${ }^{7}$, Tom Wilsgaard², Karen W Makar ${ }^{3}$, Jenny Chang-Claude ${ }^{8}$ and Inger Thune ${ }^{1,2}$

\begin{abstract}
Introduction: High mammographic density is an established breast cancer risk factor, and circulating oestrogen influences oestrogen-regulating gene expression in breast cancer development. However, less is known about the interrelationships of common variants in the CYP19A1 gene, daily levels of oestrogens, mammographic density phenotypes and body mass index (BMI) in premenopausal women.

Methods: Based on plausible biological mechanisms related to the oestrogen pathway, we investigated the association of single nucleotide polymorphisms (SNPS) in CYP19A1, 17ß-estradiol and mammographic density in 202 premenopausal women. DNA was genotyped using the Illumina Golden Gate platform. Daily salivary $17 \beta$-estradiol concentrations were measured throughout an entire menstrual cycle. Mammographic density phenotypes were assessed using a computer-assisted method (Madena). We determined associations using multivariable linear and logistic regression models.

Results: The minor alleles of rs 749292 were positively $(P=0.026)$, and the minor alleles of rs 7172156 were inversely $(P=0.002)$ associated with daily $17 \beta$-estradiol. We observed an $87 \%$ lower level of daily $17 \beta$-estradiol throughout a menstrual cycle in heavier women $\left(B M I>23.6 \mathrm{~kg} / \mathrm{m}^{2}\right.$ ) of $\mathrm{rs} 7172156$ with minor genotype aa compared with major genotype AA. Furthermore, the rs 749292 minor alleles were inversely associated with absolute mammographic density $(P=0.032)$. Lean women with rs 749292 minor alleles had 70 to $80 \%$ lower risk for high absolute mammographic density $\left(>32.4 \mathrm{~cm}^{2}\right)$; Aa: odds ratio $(\mathrm{OR})=0.23(95 \% \mathrm{Cl} 0.07$ to 0.75$)$. Lean women with rs7172156 minor homozygous genotype had OR 5.45 for high absolute mammographic density (aa: $\mathrm{OR}=5.45(95 \% \mathrm{Cl} 1.13$ to 26.3$)$ ).
\end{abstract}

Conclusion: Our findings suggest that two SNPs in CYP19A1, rs749292 and rs7172156, are associated with both daily oestrogen levels and mammographic density phenotypes. BMI may modify these associations, but larger studies are needed.

\footnotetext{
* Correspondence: v.g.flote@medisin.uio.no

${ }^{1}$ The Cancer Centre, Oslo University Hospital, Oslo N-0424, Norway

Full list of author information is available at the end of the article
} 


\section{Introduction}

Sex hormones, in particular oestrogens, are associated with breast cancer development in both pre- and postmenopausal women [1-3], and circulating oestrogens have been shown to influence oestrogen-regulating gene expression [4]. CYP19A1 is a member of the cytochrome P450 family and is involved in the bioconversion of androstenedione to oestrone and of testosterone to estradiol [5]. Human CYP19A1 is a protein commonly known as aromatase and is a gene product of CYP19A1, which is located on chromosome 15q21.2 [6]. In humans, aromatase is expressed in the gonads, adipose tissue and other sites, although the primary site of oestrogen production in premenopausal women is the ovaries [5]. Breast adipose tissue produces oestrogen locally, which may be increased in pre- and postmenopausal obese women [7], owing to higher levels of proinflammatory cytokines such as tumour necrosis factor, a known inducer of aromatase $[8,9]$. Importantly, the gene CYP19A1 is polymorphic, and the presence of single-nucleotide polymorphisms (SNPs) in the gene may alter aromatase activity, thereby causing variations in the levels of oestrogens [10].

Endogenous oestrogen has been shown to be both inversely [11,12], and positively [13-15] associated with mammographic density, and both high absolute and percent mammographic density have consistently been associated with breast cancer development [16,17]. Furthermore, mammographic density phenotypes are a strong heritable biomarker of breast cancer development, and twins studies suggest that genetic factors account for $30 \%$ to $60 \%$ of its variance $[18,19]$. In a recent meta-analysis including five genome-wide association studies, a variant (rs10995190) in the ZNF365 gene, which promotes genome stability during DNA damage, was associated with both breast cancer risk and mammographic density [20]. However, this SNP explains only $0.5 \%$ of the variance of mammographic density, and many other loci may be involved in predicting mammographic density phenotypes and breast cancer development [20].

Mammographic density is also influenced by several wellknown major breast cancer risk factors such as age, body mass index (BMI), parity, and hormone therapy [21]. Previous studies have observed an inverse association between BMI and premenopausal breast cancer development $[22,23]$. In contrast, weight gain in early adult life has been associated with postmenopausal breast cancer development [24], but the association between weight gain and premenopausal breast cancer development has not yet been clarified [25]. However, premenopausal abdominal adiposity has been associated with oestrogen receptornegative (ER-) breast cancer [26]. Studies also support excess weight being associated with higher oestrogen levels and ER+ postmenopausal breast cancer development $[27,28]$. In addition, we have previously shown that salivary estradiol concentrations are positively associated with BMI throughout the menstrual cycle in premenopausal women [29].

Few studies have been focused on genetic susceptibility, daily levels of oestrogen and premenopausal mammographic density, but plausible biological mechanisms may exist because functional genetic polymorphisms in the aromatase gene CYP19A1 have been associated with higher estradiol levels. Therefore, the main aim of the present study was to elaborate whether hypothesis-driven selected common variants in the CYP19A1 gene are associated with daily $17 \beta$-estradiol levels and mammographic density phenotypes among healthy premenopausal women and whether BMI modifies these associations.

\section{Methods}

A total of 204 women ranging in age from 25 to 35 years participated in the Norwegian Energy Balance and Breast cancer Aspects I study (EBBA-I) from 2000 to 2002 at the Department of Clinical Research, University Hospital of North Norway, Tromsø (UNN) [30]. Women meeting the following eligibility criteria were included: self-reported regular menstruation (normal cycle length, 22 to 38 days within the previous 3 months), no ongoing use of steroid contraceptives, no pregnancy or lactation in the previous 6 months, no history of gynaecological disorders and no chronic disorders (for example, diabetes, hypo- or hyperthyroidism). Two women were excluded because of missing mammographic data, resulting in 202 participants being included in the present study.

Participants' characteristics, including reproductive and lifestyle factors, were collected by one trained nurse using questionnaires and interviews at the time of recruitment. Recall and memory-probing aids, including a lifetime calendar, were used to date specific life events. Questionnaires (filled out by the participant and interviewer, administered by trained personnel) were used to collect information about birth weight, age at menarche, marital status, education, ethnicity, reproductive history, lifetime total physical activity, previous use of hormonal contraceptives and family history of cancer, smoking and alcohol. Dietary data were collected on 7 different days during the menstrual cycle (days 3 to 6 and 21 to 23) using a previously validated, precoded food diary [31]. Daily average energy and nutrient intake were computed.

\section{Clinical parameters}

Participants attended three study visits during one menstrual cycle: first visit, days 1 to 5 of the menstrual cycle, early follicular phase; second visit, days 7 to 12 , late follicular phase; and third visit, days 21 to 25 , late luteal phase. Measurements included height to the nearest $0.5 \mathrm{~cm}$ and weight (in light clothing) to the nearest $0.1 \mathrm{~kg}$ on a regularly calibrated electronic scale. BMI in kilograms per 
square metre was calculated for all participants. Fasting blood samples were drawn at all three scheduled visits during the menstrual cycle.

\section{Assessment of oestrogen}

Serum concentrations of $17 \beta$-estradiol were measured in fresh sera for all three collection points using a direct immunometric assay (Immuno-1; Bayer Diagnostics, Norway) at the Department of Clinical Chemistry, UNN [30]. The sensitivity was $0.01 \mathrm{nmol} / \mathrm{L}$, and the coefficient of variation $(\mathrm{CV})$ was $3.9 \%$.

To assess the bioavailable fraction of $17 \beta$-estradiol, the participants collected daily saliva samples during one menstrual cycle, preferably in the morning, starting on the first day of menstrual bleeding according to previously established and validated collection protocols developed at the Reproductive Ecology Laboratory of Harvard University [32] and according to the manufacturer's protocol [30]. The samples were stored at $-70^{\circ} \mathrm{C}$. All samples were run in duplicate, and samples from the same cycles were run within the same assay. The assays were done in different batches at Harvard University. 17 $\beta$ estradiol concentrations were measured in daily saliva samples using a ${ }^{125}$ I-based radioimmunoassay kit (no. 39100; Diagnostic Systems Laboratory, Webster, TX, USA). All cycles were aligned to the day of ovulation, based on the identification of the $17 \beta$-estradiol drop, which provides a reasonable estimate of the day of ovulation [33,34]. The midcycle $17 \beta$-estradiol drop could not be made for 14 of the included women, and their cycles were not aligned. Overall mean salivary $17 \beta$-estradiol concentration was calculated for all participants, whereas an additional index of mean menstrual estradiol on days -7 to +6 was calculated for the 188 women with aligned cycles. The sensitivity of the $17 \beta$-estradiol salivary assay was $4 \mathrm{pmol} / \mathrm{L}$, and the average intra-assay $\mathrm{CV}$ was $9 \%$. The measurements of $17 \beta$-estradiol had a higher CV at the start and end of the menstrual cycle, and the interassay CV ranged from 23\% (low pool) to 13\% (high pool). Furthermore, there were higher rates of missing data at the end of the cycle, so we included aligned measurements of salivary $17 \beta$-estradiol from day -7 to day +6 in this study.

\section{Assessment of mammographic density}

Bilateral two-view mammograms were obtained from women during the second scheduled visit (between cycle days 7 and 12) at the Centre of Breast Imaging, UNN, using a standard protocol [30]. The left craniocaudal mammograms were digitised and imported into a computerised mammographic density assessment programme (Madena) developed at the University of Southern California School of Medicine (Los Angeles, CA, USA) [35,36]. The density measurements were conducted by one trained reader (GU), and the total breast area was determined by a research assistant trained by GU. The total breast area was defined using a special outlining tool, and the size of this area in square centimetres using the Madena software. To assess density, the reader outlined a region of interest (ROI), excluding the pectoralis muscle, prominent veins and fibrous strands. The reader applied a tinting tool to pixels considered to represent dense areas of the mammograms within the ROI. The Madena software calculated the size of this dense area in square centimetres. Absolute mammographic breast density represented this dense area, and the percentage mammographic density was the ratio of absolute mammographic breast density to total breast area multiplied by 100 . The mammograms were read in four batches, with an equal number of mammograms included in each batch. A duplicate reading of 26 randomly selected mammograms from two of the batches showed a Pearson's correlation coefficient of 0.97 . The reader was blinded to any characteristics of the study population.

\section{Single-nucleotide polymorphism selection and genotyping} We analysed CYP19A1 genetic polymorphisms that encode the aromatase enzyme. Blood samples from 204 women in the EBBA-I study were frozen at $-70^{\circ} \mathrm{C}$. DNA was extracted from whole blood using a MagAttract DNA Blood Mini M48 kit (QIAGEN, Valencia, CA, USA) by the Department of Medical Genetics, UNN. DNA was genotyped on the Golden Gate Platform (Illumina, San Diego, CA, USA) at the Fred Hutchinson Cancer Research Center (Makar Lab), using the manufacturer's protocol. In brief, $250 \mathrm{ng}$ of genomic DNA was divided into aliquots in 96-well plates, processed accordingly and scanned on the Illumina iScan reader using BeadStudio software.

We conducted a series of quality control procedures [37]. SNP call rates exceeded $99 \%$ for this study, with $100 \%$ concordance of blinded duplicates. The linkage disequilibrium select algorithm was employed to choose the tag SNPs via the Genome Variation Server [38,39]. The SNPs were selected using an $r^{2}$ threshold of 0.8 and a minor allele frequency $>5 \%$, representing variability in the white European population. Tag SNP coverage extended 2 kilobases $(\mathrm{kb})$ upstream and $1 \mathrm{~kb}$ downstream of the gene, and 29 SNPs were covered. We further reduced the number of SNPs using power calculations and ended up with a final selection of eight common SNPs with minor allele frequency >0.2: rs10046, rs17703883, rs2414097, rs2445761, rs4646, rs7172156, rs 727479 and $r s 749292$ (see Additional file 1). None of the selected SNPs was monomorphic or significantly out of Hardy-Weinberg equilibrium.

\section{Covariate analytes}

Serum concentrations of total cholesterol were determined enzymatically using cholesterol esterase and cholesterol oxidase. High-density lipoprotein cholesterol (HDL-C) was 
quantified by direct assay using enzymes modified by polyethylene glycol and dextran sulphate.

\section{Statistical methods}

On the basis of the plausible biological mechanisms related to the oestrogen pathway, we investigated the associations between eight SNPs in the CYP19A1 gene, hormone levels (salivary midmenstrual $17 \beta$-estradiol and serum $17 \beta$-estradiol) and mammographic density phenotypes (total breast area, absolute mammographic density, percent mammographic density and nondense breast area) using multivariable linear regression models. Associations were assessed for the selected SNPs, and the selected SNPs were coded as $A A=0$ (major homozygous), $A a=1$ (heterozygous) and $a a=2$ (minor homozygous) and were included as ordinal variables in the models. We compared the linear response between the categories of genotypes by including indicator variables for $A a$ and $a a$, using $A A$ as the reference.

Age, parity and BMI are known to be associated with mammographic density phenotypes, are possibly associated with hormone levels and/or CYP19A1 variants, and were therefore considered as potential confounders and included as covariates in all models [21]. Furthermore, the models with mammographic density as the dependent variable also included salivary $17 \beta$-estradiol and serum HDL-C, both of which are known to influence mammographic density $[40,13]$. In the final analyses, we focused on two selected SNPs (rs7172156 and rs749292) and stratified the women by major, heterozygous and minor genotypes. We then compared the genotype groups using different characteristics of the study population (lifestyle factors, anthropometric measures, serum blood sampling and salivary hormone sampling), and we used one-way analysis of variance for continuous variables and the $x^{2}$ test for categorical variables.

The multivariable logistic regression models were run using median absolute mammographic density $\left(32.4 \mathrm{~cm}^{2}\right)$ and median percent mammographic density $(28.5 \%)$ as cutoff values. Mammographic density was used as a dependent variable, and rs7172156 and rs749292 were used as independent variables, adjusted for age, parity and BMI. In addition, we analysed in detail whether BMI variations influenced our results (that is, tertiles/dichotomised $\mathrm{BMI}$ ), but only dichotomised BMI by median BMI values gave additional information and thus were included in the final analysis.

We used linear mixed models for repeated measures to study variations of daily salivary $17 \beta$-estradiol across the menstrual cycle for subgroups of women with major, minor homozygous or heterozygous genotypes in the SNPs rs7172156 and rs749292, and we then adjusted for age, BMI and parity. The Toeplitz covariance structure gave the best fit to the data and was used in all models.
Our candidate polymorphisms were based on plausible biological hypotheses, and all $P$-values were two-tailed and considered significant when the value was $<0.05$. The analyses were conducted with SPSS version 21.0 software (IBM, Armonk, NY, USA).

\section{Ethical considerations}

All participants underwent informed consent procedures and signed a consent form. The study was approved by the Norwegian Data Inspectorate and the Regional Committee for Medical Research Ethics.

\section{Results}

The participating premenopausal women had mean values (standard deviation (SD)) for age of 30.7 (3.07) years and BMI of $24.4(3.77) \mathrm{kg} / \mathrm{m}^{2}$ (Table 1). When we stratified the women into groups for $r s 749292$ and $r s 7172156$ by major homozygous, heterozygous and minor homozygous genotypes, we observed no differences in lifestyle factors, anthropometric measures or serum analytes (Table 1).

We observed an association between two SNPs (rs749292, rs7172156) and both salivary estradiol and absolute mammographic density. Moreover, a positive association was observed between $r s 749292$ and midmenstrual salivary $17 \beta$-estradiol $(P=0.026)$, and an inverse association between $r$ s7172156 and midmenstrual salivary $17 \beta$-estradiol $(P=0.002)$, after adjustment for age, BMI and parity (Table 2). We also observed a negative association between rs749292 and absolute mammographic density $(P=0.032)$ after adjusting for age, BMI, parity, salivary midmenstrual $17 \beta$-estradiol and serum HDL-C.

\section{rs749292, rs7172156 and oestrogen levels}

The associations between $r 5749292$ and $r s 7172156$ with $17 \beta$-estradiol were studied further with multivariable linear regression analyses. For rs749292, we observed a positive association between the minor homozygous genotype (aa) and salivary $17 \beta$-estradiol $(\beta=3.79, P=0.03)$. For rs7172156, we observed an inverse association between the minor homozygous genotype and salivary $17 \beta$-estradiol $(\beta=-6.96, P<0.001)$ (Table 2). We then dichotomized participants by median split of BMI $\left(23.6 \mathrm{~kg} / \mathrm{m}^{2}\right)$. For rs7172156, the minor homozygous genotype $(a a)$ was inversely associated with $17 \beta$-estradiol levels (aa: $\beta=-10.2$, $P<0.001)$ in women with a high BMI $\left(>23.6 \mathrm{~kg} / \mathrm{m}^{2}\right)$ (Table 3).

No clear association was observed between any of these SNPs and serum levels of $17 \beta$-estradiol at any of the three measured time periods (early follicular, late follicular or late luteal phase) of the menstrual cycle. In the mixed linear regression models, we found that women with different genotypes of $r s 7172156$ varied in the levels of average midmenstrual salivary $17 \beta$-estradiol $(P=0.001)$. Among women with genotype $A A$ and genotype $A a$, 
Table 1 Characteristics of the Norwegian EBBA-I study population overall and by CYP19A1 single-nucleotide polymorphisms rs7172156 and rs749292

\begin{tabular}{|c|c|c|c|c|c|c|c|c|c|}
\hline \multirow{2}{*}{$\begin{array}{l}\text { Study } \\
\text { characteristics }\end{array}$} & \multirow{2}{*}{$\begin{array}{l}\text { Overall } \\
\text { means (SD) }\end{array}$} & \multicolumn{4}{|l|}{$r s 7172156$} & \multicolumn{4}{|l|}{ rs749292 } \\
\hline & & $\begin{array}{l}\text { Major } \\
\text { genotype, } A A \\
(n=82)^{\mathrm{a}} \\
\end{array}$ & $\begin{array}{l}\text { Heterozygous } \\
\text { genotype, } A a \\
(n=91)^{a}\end{array}$ & $\begin{array}{l}\text { Minor } \\
\text { genotype, aa } \\
(n=31)^{a}\end{array}$ & $P$-value ${ }^{\mathrm{b}}$ & $\begin{array}{l}\text { Major } \\
\text { genotype, } A A \\
(n=62)^{\mathrm{a}}\end{array}$ & $\begin{array}{l}\text { Heterozygous } \\
\text { genotype, } A a \\
(n=93)^{a}\end{array}$ & $\begin{array}{l}\text { Minor } \\
\text { genotype, aa } \\
(n=48)^{\mathrm{a}}\end{array}$ & $P$-value ${ }^{b}$ \\
\hline Age (yr) & $30.7(3.07)$ & $30.2(3.09)$ & $31.1(3.12)$ & $30.7(2.79)$ & 0.149 & $30.5(2.99)$ & $31.0(3.17)$ & $30.4(3.00)$ & 0.425 \\
\hline Education (total yr) & $16.1(3.01)$ & $15.9(2.65)$ & $16.2(3.41)$ & $16.3(2.73)$ & 0.701 & $15.8(3.02)$ & $16.3(3.15)$ & $16.2(2.70)$ & 0.603 \\
\hline \multicolumn{10}{|l|}{ Reproductive factors ${ }^{c}$} \\
\hline Age at menarche (yr) & $13.1(1.36)$ & $13.1(1.40)$ & $13.2(1.43)$ & $13.1(1.04)$ & 0.793 & $13.0(1.14)$ & $13.2(1.52)$ & $13.2(1.20)$ & 0.536 \\
\hline $\begin{array}{l}\text { Menstrual cycle } \\
\text { length (days) }\end{array}$ & $28.3(3.42)$ & $28.7(3.01)$ & $28.2(3.66)$ & $27.8(3.69)$ & 0.463 & $28.0(3.48)$ & $28.3(3.50)$ & $28.8(3.22)$ & 0.503 \\
\hline Number of children & $0.91(1.13)$ & $0.85(1.17)$ & $0.98(1.11)$ & $0.84(1.10)$ & 0.721 & $0.73(1.01)$ & $0.99(1.12)$ & $0.98(1.28)$ & 0.320 \\
\hline Weight at birth (g) & $3,389(561)$ & $3,428(554)$ & $3,369(585)$ & 3,343 (519) & 0.701 & $3,274(574)$ & $3,507(530)$ & $3,328(556)$ & 0.024 \\
\hline \multicolumn{10}{|l|}{ Clinical parameters } \\
\hline $\operatorname{BMI}\left(\mathrm{kg} / \mathrm{m}^{2}\right)^{\mathrm{d}}$ & $24.4(3.77)$ & $24.4(3.74)$ & $24.2(3.73)$ & $25.0(4.00)$ & 0.606 & $24.8(4.66)$ & $24.1(3.19)$ & $24.3(3.33)$ & 0.467 \\
\hline $\begin{array}{l}\text { Total tissue fat (\%) } \\
(\text { DXA })^{e}\end{array}$ & $34.2(7.62)$ & $33.9(7.69)$ & $33.7(7.92$ & $36.0(6.41)$ & 0.328 & $35.1(8.10)$ & $33.5(7.51)$ & $33.9(7.08)$ & 0.455 \\
\hline \multicolumn{10}{|l|}{ Serum samples ${ }^{f}$} \\
\hline $\begin{array}{l}\text { Total cholesterol } \\
(\mathrm{mmol} / \mathrm{L})\end{array}$ & $4.45(0.78)$ & $4.55(0.84)$ & $4.36(0.75)$ & $4.40(0.71)$ & 0.268 & $4.45(0.77)$ & $4.33(0.79)$ & $4.68(0.76)$ & 0.044 \\
\hline HDL-C (mmol/L) & $1.54(0.33)$ & $1.55(0.30)$ & $1.54(0.36)$ & $1.51(0.34)$ & 0.833 & $1.53(0.32)$ & $1.54(0.36)$ & $1.55(0.31)$ & 0.940 \\
\hline \multicolumn{10}{|l|}{ Serum hormones ${ }^{f}$} \\
\hline Estradiol (nmol/L) & $0.15(0.06)$ & $0.15(0.06)$ & $0.15(0.07)$ & $0.14(0.06)$ & 0.644 & $0.14(0.06)$ & $0.15(0.07)$ & $0.14(0.06)$ & 0.646 \\
\hline SHBG (nmol/L) & $51.9(19.5)$ & $51.7(18.1)$ & $52.7(22.0)$ & $50.2(15.3)$ & 0.828 & $51.6(17.0)$ & $53.3(22.8)$ & $50.0(15.5)$ & 0.626 \\
\hline \multicolumn{10}{|l|}{ Salivary hormones ${ }^{g}$} \\
\hline $\begin{array}{l}\text { Midmenstrual } \\
\text { estradiol (pmol/L) }\end{array}$ & $18.2(8.98)$ & $19.4(9.52)$ & $19.0(8.81)$ & $12.6(5.39)$ & 0.001 & $16.3(7.67)$ & $18.4(9.59)$ & $19.8(9.03)$ & 0.095 \\
\hline \multicolumn{10}{|l|}{ Lifestyle factors ${ }^{c}$} \\
\hline Current smokers (\%) & 22.3 & 19.3 & 22.8 & 28.1 & 0.586 & 13.8 & 23.2 & 10.8 & 0.768 \\
\hline Alcohol (U/wk) & $2.89(3.38)$ & $3.03(3.41)$ & $2.84(3.38)$ & $2.67(3.38)$ & 0.865 & $2.52(3.07)$ & $3.07(3.41)$ & $3.08(3.74)$ & 0.561 \\
\hline $\begin{array}{l}\text { Energy intake } \\
\text { (kJ/day) }\end{array}$ & $8,093(1,900)$ & $8,371(1,837)$ & $8,085(1,754)$ & $7,381(2,314)$ & 0.046 & $7,749(1,975)$ & $8,087(2,005)$ & $8,495(1,480)$ & 0.123 \\
\hline $\begin{array}{l}\text { Previous use of } \\
\text { OC (\%) }\end{array}$ & 83.4 & 81.9 & 85.7 & 81.2 & 0.747 & 81.0 & 83.9 & 85.7 & 0.788 \\
\hline $\begin{array}{l}\text { Leisure time MET } \\
\text { (hr/wk) }\end{array}$ & $57.6(88.6)$ & $68.2(133)$ & $48.4(32.0)$ & $56.7(42.9)$ & 0.337 & $51.9(39.4)$ & $63.4(125)$ & $53.6(36.8)$ & 0.685 \\
\hline \multicolumn{10}{|l|}{$\begin{array}{l}\text { Mammographic } \\
\text { density }\end{array}$} \\
\hline Total area $\left(\mathrm{cm}^{2}\right)$ & $137(62.5)$ & $131(64.9)$ & 137 (59.6) & $155(62.8)$ & 0.209 & $149(69.5)$ & $132(61.1)$ & 129 (52.6) & 0.161 \\
\hline $\begin{array}{l}\text { Absolute density } \\
\left(\mathrm{cm}^{2}\right)\end{array}$ & $34.7(23.4)$ & $34.7(22.4)$ & $32.8(23.8)$ & $40.7(24.4)$ & 0.283 & $39.1(26.2)$ & $33.5(23.8)$ & 32.3 (17.4) & 0.238 \\
\hline Percent density (\%) & $29.8(19.0)$ & $31.5(19.0)$ & $28.6(20.4)$ & $28.8(14.5)$ & 0.594 & $30.1(18.1)$ & $29.8(20.2)$ & $29.9(17.9)$ & 0.995 \\
\hline
\end{tabular}

Numbers in parentheses are standard deviations (SDs). BMI, body mass index; $E_{2}$, 17ß-estradiol; DXA, Dual-energy X-ray absorptiometry; HDL-C, High-density lipoprotein-cholesterol; LDL-C, Low-density lipoprotein-cholesterol; MET, Metabolic equivalent; OC, Oral contraceptives; SHBG, Sex hormone-binding globulin. ${ }^{\mathrm{a}}$ Numbers may vary due to missing information. ${ }^{\mathrm{b}}$ OneWay ANOVA or $X^{2}$ test, significance level $P<0.05$. ${ }^{\mathrm{c}}$ Questionnaires. ${ }^{\mathrm{d}} \mathrm{Measurements}$ at days 1 to 5 after onset

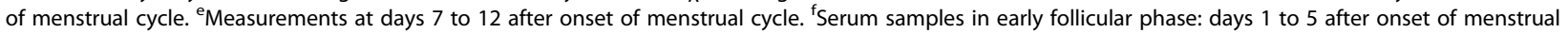
cycle. ${ }^{9}$ Daily salivary samples throughout one entire menstrual cycle.

compared with women with genotype $a a, 57 \%$ and $56 \%$ higher mean $17 \beta$-estradiol levels were observed, respectively (Figure 1d). This association was even more marked when we dichotomised the data by median split of BMI $\left(23.6 \mathrm{~kg} / \mathrm{m}^{2}\right)$. We observed an $87 \%$ lower level of mean
$17 \beta$-estradiol throughout a menstrual cycle in heavier women (BMI $>23.6 \mathrm{~kg} / \mathrm{m}^{2}$ ) with minor genotype $a a$ of rs7172156 compared with those with major genotype $A A$ (Figure 1f). Among women with genotype $A A$, heavier women had a $33 \%$ higher level of $17 \beta$-estradiol compared 
Table 2 Associations between two CYP19A1 single-nucleotide polymorphisms (rs749292, rs7172156) and 17 $\beta$-estradiol

\begin{tabular}{|c|c|c|c|c|c|}
\hline CYP19A1 SNPs & Location & Frequencies & Genotype & $\beta$-value $(95 \% \mathrm{Cl})$ & $P$-value \\
\hline rs749292 & Intron & & & & \\
\hline \multirow[t]{3}{*}{ Salivary $17 \beta$-estradiol } & & 0.283 & $A A$ & Reference & \\
\hline & & 0.457 & $A a$ & $2.73(-0.22,5.68)$ & 0.069 \\
\hline & & 0.26 & $a a$ & $3.79(0.39,7.20)$ & 0.029 \\
\hline$P$-value for trend & & & & & 0.026 \\
\hline \multirow[t]{3}{*}{ Serum $17 \beta$-estradiol } & & & $A A$ & Reference & \\
\hline & & & $A a$ & $6.77(-13.4,26.9)$ & 0.509 \\
\hline & & & $a a$ & $0.73(-22.8,24.2)$ & 0.951 \\
\hline$P$-value for trend & & & & & 0.905 \\
\hline rs7172156 & Intron & & & & \\
\hline \multirow[t]{3}{*}{ Salivary $17 \beta$-estradiol } & & 0.406 & $A A$ & Reference & \\
\hline & & 0.444 & $\mathrm{Aa}$ & $-0.10(-2.76,2.56)$ & 0.939 \\
\hline & & 0.15 & $a a$ & $-6.96(-10.6,-3.32)$ & $<0.001$ \\
\hline$P$-value for trend & & & & & 0.002 \\
\hline \multirow[t]{3}{*}{ Serum $17 \beta$-estradiol } & & & $A A$ & Reference & \\
\hline & & & $\mathrm{Aa}$ & $-3.38(-22.1,15.3)$ & 0.722 \\
\hline & & & $a a$ & $-12.4(-38.1,13.2)$ & 0.340 \\
\hline$P$-value for trend & & & & & 0.365 \\
\hline
\end{tabular}

to leaner women. However, in genotype $a a$, there was no increase in $17 \beta$-estradiol levels when we compared leaner and heavier women. When comparing mean $17 \beta$-estradiol levels in lean women (BMI $\leq 23.6 \mathrm{~kg} / \mathrm{m}^{2}$ ) with $r s 749292$ major genotype $A A$ with heavier women $\left(\mathrm{BMI}>23.6 \mathrm{~kg} / \mathrm{m}^{2}\right.$ ) with rs749292 minor genotype $a a$, a 52\% higher mean $17 \beta$-estradiol level was observed (Figure 1).

\section{rs749292 and rs7172156 and mammographic density phenotypes}

The association between the SNPs and mammographic density phenotypes was studied with multivariable linear regression models. For rs749292, we observed an inverse association between minor alleles $(A a, a a)$ and absolute mammographic density (Table 4 ). We observed a positive association between $r s 7172156$ minor genotype $a a$ and absolute mammographic density.

After dichotomising by median split of BMI, we found that $r s 749292$ minor alleles were inversely associated with absolute mammographic density $(A a: \beta=-13.0, P=0.006$; aa: $\beta=-14.1, P=0.010)$ in lean women $\left(\leq 23.6 \mathrm{~kg} / \mathrm{m}^{2}\right)$, but not in women with a BMI $>23.6 \mathrm{~kg} / \mathrm{m}^{2}$. Among lean women $\left(\leq 23.6 \mathrm{~kg} / \mathrm{m}^{2}\right)$ with $r s 7172156$ genotype $a a$, we observed a positive association with absolute mammographic density (aa: $\beta=18.2, P=0.005$ ) (Table 4 ).

In the multivariable logistic regression models, lean women (BMI $\leq 23.6 \mathrm{~kg} / \mathrm{m}^{2}$ ) who had rs749292 minor alleles $(A a, a a)$ had an $80 \%$ lower risk for high percent mammographic density (above median: $>28.5 \%)(A a$ : $\mathrm{OR}=0.19$ (95\% CI, 0.05 to 0.82$)$; aa: $\mathrm{OR}=0.17$ (95\% CI 0.03 to 0.82$)$ ). The results were similar but attenuated for absolute mammographic density (Table 5 ).

For $r$ 7172156, lean women with a minor homozygous genotype had a 5.45 higher OR for high absolute mammographic density (aa: OR $=5.45$ (95\% CI, 1.13 to 26.3)). Similar associations were observed for rs7172156 and percent mammographic density (Table 5).

\section{Discussion}

In the present study of premenopausal women, two SNPs (rs749292, rs7172156) of eight studied in the CYP19A1 gene were related to both daily salivary $17 \beta$-estradiol and mammographic density phenotypes. The association with mammographic density was revealed when we used salivary $17 \beta$-estradiol as a covariate, and similar results were observed for absolute and percent mammographic density. Furthermore, our results suggest that body weight may modify these associations. We observed an $87 \%$ lower level of daily $17 \beta$-estradiol throughout a menstrual cycle in heavier women $\left(\mathrm{BMI}>23.6 \mathrm{~kg} / \mathrm{m}^{2}\right)$ with minor genotype aa (17 $\beta$-estradiol $12.3 \mathrm{pmol} / \mathrm{L})$ of $r s 7172156$ compared with major genotype $A A$ (17ß-estradiol $22.4 \mathrm{pmol} / \mathrm{L})$. Furthermore, lean women with rs7172156 minor homozygous genotype $a a$ had a fivefold higher OR for high absolute 
Table 3 Associations between the CYP19A1 single-nucleotide polymorphisms (rs749292, rs7172156) and 17ß-estradiol by median body mass index $\left(23.6 \mathrm{~kg} / \mathrm{m}^{2}\right)$

\begin{tabular}{|c|c|c|c|}
\hline & Genotype & $\beta$-value $(95 \% \mathrm{Cl})$ & $P$-value \\
\hline \multicolumn{4}{|l|}{ rs749292 } \\
\hline \multicolumn{4}{|c|}{ Salivary $17 \beta$-estradiol } \\
\hline \multirow[t]{3}{*}{$\mathrm{BMI} \leq 23.6 \mathrm{~kg} / \mathrm{m}^{2}$} & $A A$ & Reference & \\
\hline & $A a$ & $2.72(-1.06,6.50)$ & 0.157 \\
\hline & $a a$ & $2.79(-1.54,7.12)$ & 0.203 \\
\hline$P$-value for trend & & & 0.197 \\
\hline \multirow[t]{3}{*}{$\mathrm{BMI}>23.6 \mathrm{~kg} / \mathrm{m}^{2}$} & $A A$ & Reference & \\
\hline & $A a$ & $3.08(-1.79,7.96)$ & 0.212 \\
\hline & $a a$ & $5.26(-0.32,10.8)$ & 0.064 \\
\hline$P$-value for trend & & & 0.059 \\
\hline \multicolumn{4}{|l|}{ rs 7172156} \\
\hline \multicolumn{4}{|c|}{ Salivary $17 \beta$-estradiol } \\
\hline \multirow[t]{3}{*}{$\mathrm{BMI} \leq 23.6 \mathrm{~kg} / \mathrm{m}^{2}$} & $A A$ & Reference & \\
\hline & $A a$ & $0.78(-2.63,4.19)$ & 0.650 \\
\hline & $a a$ & $-3.98(-9.11,1.14)$ & 0.126 \\
\hline$P$-value for trend & & & 0.326 \\
\hline \multirow[t]{3}{*}{$\mathrm{BMI}>23.6 \mathrm{~kg} / \mathrm{m}^{2}$} & $A A$ & Reference & \\
\hline & $\mathrm{Aa}$ & $-1.26(-5.62,3.11)$ & 0.569 \\
\hline & $a a$ & $-10.2(-15.7,-4.68)$ & $<0.001$ \\
\hline$P$-value for trend & & & 0.001 \\
\hline
\end{tabular}

Multivariable linear regression model adjusted for age, body mass index (BMI) and parity. $\beta$ : Estimated slope coefficient (for example, change in response) from reference value $(A A)$ to $A a$ and $a a$. Salivary midmenstrual $17 \beta$-estradiol is the average of aligned menstrual estradiol levels from days -7 to +6 .

mammographic density compared with major homozygous genotype $A A$. Lean women who had $r s 749292$ minor alleles had $70 \%$ to $80 \%$ lower risk for high absolute and high percent mammographic density compared with major homozygous genotype $A A$.

The CYP19 activity is responsible for the bioconversion of androgens to oestrogens [5,6], and to our knowledge, there have been few studies related to CYP19A1 SNPs, daily levels of oestrogen throughout an entire menstrual cycle and mammographic density phenotypes in premenopausal women. It is not clear why and how noncoding SNPs influence the gene activity, but previous genome-wide association studies have shown intronic SNPs to be important breast cancer risk loci [41]. This does not necessarily imply that the SNPs are causal, but it may help to identify novel susceptibility loci. In addition, intronic SNPs may regulate gene expression through endogenous trans-acting factors, epigenetics and chromosome conformation [42]. Our results are in part supported by a previous report [10] that $r s 749292$ minor alleles were associated with a $10 \%$ to $20 \%$ increase in oestrogen levels among postmenopausal women in a combined analysis of five cohort studies. Other SNPs in the CYP19A1 gene have also been studied, and in one study on postmenopausal women with a mean age of 57 years and a mean BMI of $24.2 \mathrm{~kg} / \mathrm{m}^{2}$, researchers found an association with circulating oestrogen levels, but only among women with BMI $>25 \mathrm{~kg} / \mathrm{m}^{2}$ [43]. Interestingly, functional genetic polymorphisms may also influence the level of estradiol in women undergoing inhibitory treatment, as two CYP19A1 SNPs were associated with higher estradiol levels, particularly after initiation of aromatase inhibitors [44]. These findings imply that CYP19A1 SNPs may be of clinical interest, as aromatase inhibitor treatment has been shown to be one of the most effective modern antihormonal breast cancer treatment regimens. To our knowledge, no clear associations have been observed between CYP19A1 SNPs and mammographic density [45], and researchers in one study found no associations of oestrogen synthesis or oestrogen metabolism genes with mammographic density in a mixed population of perimenopausal, young postmenopausal and postmenopausal women [45]. Few known genetic variants predict both mammographic density and breast cancer risk, but Lindstrom et al. found an association between common variants in the ZNF365 gene, which promotes genome stability under DNA damage, with both mammographic density and breast cancer development [20]. In addition, SNPs in the inflammatory gene interleukin-6 (IL-6) have recently been associated with premenopausal percent mammographic density [46]. Despite the clear association of endogenous oestrogens with breast cancer development [1], results have been inconsistent regarding associations between CYP19A1 variants and risk for breast cancer [10,47-49], but rs1008805 [50] and, recently, rs10046 were observed to be associated with breast cancer susceptibility among premenopausal women [51].

Elevated BMI has been related to higher levels of sex hormones in both premenopausal [30] and postmenopausal women [52], and weight loss through diet and exercise may reduce sex steroid hormone levels in premenopausal [53] and postmenopausal women [54]. We previously observed that CYP17 polymorphisms were associated with $17 \beta-$ estradiol levels, especially in women with unfavourable metabolic profiles [55]. Interestingly, in the present study, an inverse association was observed between $r 5749292$ minor alleles and absolute mammographic density among lean women, but this association disappeared in heavier women. Furthermore, rs 7172156 minor alleles were associated with higher absolute mammographic density among lean women. In contrast, we found that among women with minor alleles and high BMI, rs7172156 may be a protective polymorphism associated with lower $17 \beta$-estradiol and lower OR for having above-median percent mammographic density $(>28.5 \%)$ and absolute mammographic density $\left(>32.4 \mathrm{~cm}^{2}\right)$. Similar mammographic threshold estimates of $25 \%$ mammographic density and $32-\mathrm{cm}^{2}$ absolute mammographic density have been shown 


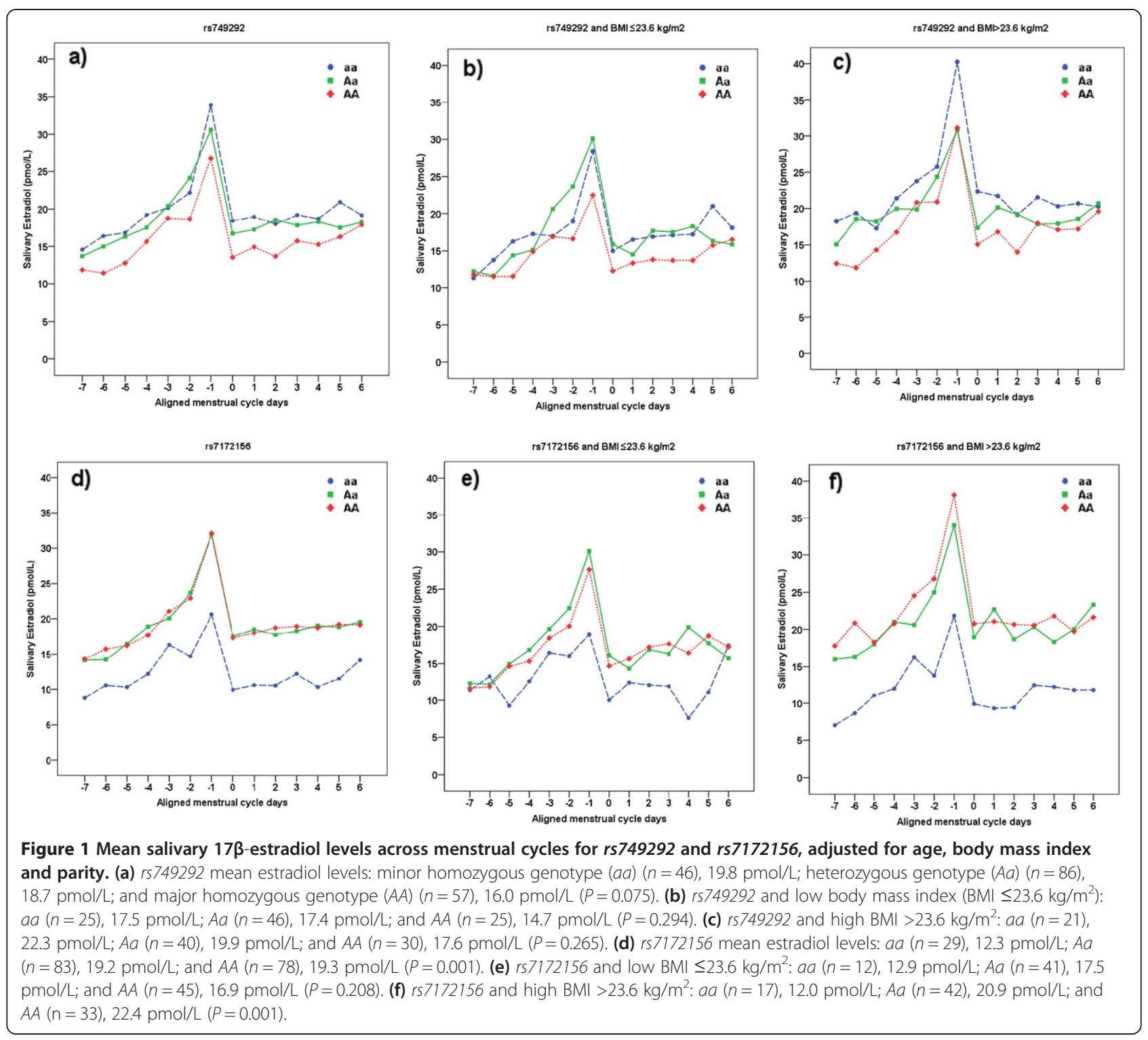

to predict a two- to threefold risk of breast cancer development within 5 to 10 years $[56,57]$.

Interestingly, a previous study observed an association between $r s 7172156$, rs749292 [58] and serum levels of hepatocyte growth factor (HGF). HGF is a cytokine derived from adipose tissue [58] that promotes cell migration, proliferation and invasion, and previous studies have found associations between HGF levels and development from benign breast disorders to preinvasive, basal-like breast cancer [59], as well as further correlations with poor prognosis. These findings lead us to hypothesize that there may be a biological rational for the associations we observed for two SNPs in CYP19A1: rs7172156 and rs749292.

Our study has several strengths. These are inclusion of premenopausal women; clinical measurements carefully timed to the menstrual cycle, including mammographic density phenotypes and serum and daily saliva $17 \beta$ estradiol; and a validated computer-assisted method for quantifying mammographic density. In contrast, we did not observe the same associations between these two SNPs in CYP19A1 and serum 17 $\beta$-estradiol as we did for salivary $17 \beta$-estradiol. Importantly, salivary $17 \beta$-estradiol was assessed daily, is the free bioavailable fraction and is not bound to albumin or sex hormone-binding globulin, in contrast to the serum $17 \beta$-estradiol levels, and may in part explain the variations observed [30,33]. Previous research has indicated that single measurements of serum oestrogen do not accurately reflect women's long-term oestrogen levels [3], whereas multiple measurements of unbound bioavailable levels probably give a picture of the real endogenous cumulative exposure over time. This means that single measurements are likely to be an 
Table 4 Association between CYP19A1 single-nucleotide polymorphisms (rs749292 and rs7172156) and mammographic density phenotypes, overall and stratified by median body mass index $\left(23.6 \mathrm{~kg} / \mathrm{m}^{2}\right)$

\begin{tabular}{|c|c|c|c|c|c|c|c|}
\hline \multirow{2}{*}{$\begin{array}{l}\text { Mammographic } \\
\text { density }\end{array}$} & \multirow[b]{2}{*}{ Genotype } & \multicolumn{2}{|l|}{ Total } & \multicolumn{2}{|l|}{$\mathrm{BMI} \leq 23.6$} & \multicolumn{2}{|l|}{$\mathrm{BMI}>23.6$} \\
\hline & & $\begin{array}{l}\beta \text {-value }(95 \% \mathrm{Cl}) \\
(n=202)\end{array}$ & $P$-value & $\begin{array}{l}\beta \text {-value }(95 \% \mathrm{Cl}) \\
(n=101)\end{array}$ & $P$-value & $\begin{array}{l}\beta \text {-value }(95 \% \mathrm{Cl}) \\
(n=101)\end{array}$ & $P$-value \\
\hline \multicolumn{8}{|l|}{ rs749292 } \\
\hline \multirow[t]{3}{*}{ Absolute density } & $A A$ & Reference & & Reference & & Reference & \\
\hline & $A a$ & $-7.78(-15.5,-0.12)$ & 0.047 & $-13.0(-22.2,-3.82)$ & 0.006 & $1.91(-9.86,13.7)$ & 0.748 \\
\hline & $a a$ & $-9.47(-18.3,-0.61)$ & 0.036 & $-14.1(-24.8,-3.44)$ & 0.010 & $-1.36(-14.9,12.2)$ & 0.842 \\
\hline$P$-value for trend & & & 0.032 & & 0.015 & & 0.587 \\
\hline \multirow[t]{3}{*}{ Percent density } & $A A$ & Reference & & Reference & & Reference & \\
\hline & $A a$ & $-2.64(-7.68,2.39)$ & 0.301 & $-3.01(-10.0,4.01)$ & 0.396 & $2.44(-3.93,8.82)$ & 0.449 \\
\hline & $a a$ & $-2.68(-8.50,3.14)$ & 0.364 & $-2.33(-10.5,5.81)$ & 0.571 & $0.42(-6.92,7.76)$ & 0.910 \\
\hline$P$-value for trend & & & 0.348 & & 0.537 & & 0.866 \\
\hline \multicolumn{8}{|l|}{ rs7172156 } \\
\hline \multirow[t]{3}{*}{ Absolute density } & $A A$ & Reference & & Reference & & Reference & \\
\hline & $A a$ & $0.27(-6.70,7.24)$ & 0.939 & $3.94(-4.63,12.5)$ & 0.363 & $-4.87(-15.9,6.15)$ & 0.768 \\
\hline & $a a$ & $11.6(1.43,21.8)$ & 0.026 & $18.2(5.67,30.8)$ & 0.005 & $-2.15(-16.6,12.3)$ & 0.382 \\
\hline$P$-value for trend & & & 0.074 & & 0.011 & & 0.978 \\
\hline \multirow[t]{3}{*}{ Percent density } & $A A$ & Reference & & Reference & & Reference & \\
\hline & $A a$ & $-1.52(-6.09,3.05)$ & 0.512 & $1.15(-5.38,7.67)$ & 0.728 & $-4.98(-10.9,0.93)$ & 0.097 \\
\hline & $a a$ & $2.23(-4.45,8.91)$ & 0.512 & $2.01(-7.57,11.6)$ & 0.678 & $-2.26(-9.99,5.47)$ & 0.563 \\
\hline$P$-value for trend & & & 0.792 & & 0.573 & & 0.847 \\
\hline
\end{tabular}

Multivariable linear regression model adjusted for age, parity, body mass index (BMI), 17- $\beta$-estradiol and high-density lipoprotein cholesterol. $\beta$ : Estimated slope coefficient (for example, change in response) from reference ( $A A$ ) to $A a$ and $a a$. Mammograms were taken within late follicular phase from days 7 to 12 .

Table 5 Adjusted odds ratios for above-median absolute mammographic density $\left(>32.4 \mathrm{~cm}^{2}\right)$ and above-median percent mammographic density $(>28.5 \%)$ by CYP19A1 single-nucleotide polymorphism and stratified by median body mass index $\left(23.6 \mathrm{~kg} / \mathrm{m}^{2}\right)$

\begin{tabular}{|c|c|c|c|c|}
\hline Mammographic density & Genotype & $\begin{array}{l}\text { Total }(n=202) \\
\text { OR }(95 \% \mathrm{Cl})\end{array}$ & $\begin{array}{l}\text { BMI } \leq 23.6(n=101) \\
\text { OR }(95 \% \mathrm{Cl})\end{array}$ & $\begin{array}{l}\text { BMI }>23.6(n=101) \\
\text { OR }(95 \% \mathrm{Cl})\end{array}$ \\
\hline \multicolumn{5}{|l|}{ rs749292 } \\
\hline \multirow[t]{3}{*}{ Absolute density } & $A A$ & 1.0 & 1.0 & 1.0 \\
\hline & $A a$ & $0.59(0.29,1.22)$ & $0.23(0.07,0.75)$ & $1.28(0.45,3.63)$ \\
\hline & $a a$ & $0.86(0.37,1.98)$ & $0.28(0.08,1.05)$ & $2.21(0.68,7.15)$ \\
\hline \multirow[t]{3}{*}{ Percent density } & $A A$ & 1.0 & 1.0 & 1.0 \\
\hline & $A a$ & $0.57(0.25,1.30)$ & $0.19(0.05,0.82)$ & $1.41(0.42,4.74)$ \\
\hline & $a a$ & $0.64(0.25,1.64)$ & $0.17(0.03,0.82)$ & $1.85(0.49,6.99)$ \\
\hline \multicolumn{5}{|l|}{ rs7172156 } \\
\hline \multirow[t]{3}{*}{ Absolute density } & $A A$ & 1.0 & 1.0 & 1.0 \\
\hline & $A a$ & $0.76(0.39,1.48)$ & $1.49(0.56,3.97)$ & $0.35(0.13,0.94)$ \\
\hline & $a a$ & $1.16(0.47,2.88)$ & $5.45(1.13,26.3)$ & $0.34(0.09,1.25)$ \\
\hline \multirow[t]{3}{*}{ Percent density } & $A A$ & 1.0 & 1.0 & 1.0 \\
\hline & $A a$ & $0.85(0.40,1.82)$ & $1.91(0.64,5.68)$ & $0.40(0.13,1.22)$ \\
\hline & $a a$ & $1.40(0.51,3.82)$ & $5.48(0.92,32.7)$ & $0.45(0.11,1.87)$ \\
\hline
\end{tabular}

Multivariable logistic regression adjusted for age, body mass index (BMI) and parity and stratified by median $\mathrm{BMI}\left(23.6 \mathrm{~g} / \mathrm{m}^{2}\right) . \mathrm{Major}$ homozygous genotype $A A$, heterozygous genotype $A a$ and minor homozygous genotype $a a$. Absolute mammographic density with median $32.4 \mathrm{~cm}^{2}$ as cutoff. Percent mammographic density with median $28.5 \%$ as cutoff. $\mathrm{Cl}$ : Confidence interval; OR: Odds ratio. 
underestimate because they do not capture the premenopausal cyclical changes and will be imperfect estimates of the true pattern $[3,60]$. Thus, use of exploratory, noninvasive, repeated sampling of salivary hormones may provide new knowledge on the true association between hormones and breast cancer. Moreover, this may in part explain why circulating oestrogen levels consistently have been observed to increase risk, as well as risk prediction for invasive postmenopausal breast cancer [61], but the association between endogenous oestrogen levels and breast cancer among premenopausal women is less clear [3]. Today, liquid chromatography-tandem mass spectrometry, as compared to the immunoassay method, is a more efficient way of analysing salivary hormones with higher specificity and sensitivity. However, previous studies on estradiol measurements, specifically, have shown a correlation of 0.969 between mass spectrometry and immunoassays [62]. However, our sample size was small, and associations could have been missed by chance. Furthermore, the population was a sample of volunteer participants and therefore may not be representative of the source population, but their average BMI and other lifestyle-related factors and lipid profiles are in accordance with the population of premenopausal Norwegian women [63]. A limited number of SNPs were examined, based on the biological hypothesis that polymorphisms in the CYP19 gene may influence $17 \beta$-estradiol levels and mammographic phenotypes. Even though only eight SNPs were examined, there is a risk of false-positive results. Nevertheless, our findings are intriguing and support future research in larger sample sizes.

\section{Conclusion}

In the present study, we found associations between two CYP19A1 SNPs (rs7172156 and rs749292) and both daily $17 \beta$-estradiol throughout an entire menstrual cycle and both absolute and percent mammographic density in premenopausal women, and the results differed between lean and heavier women. This observation suggests that there may be genetic influences on these breast cancer biomarkers and also that the effect of body size may play a major role. Future research on genetic control of mammographic density phenotypes and sex hormones should include exploratory salivary hormone measurements and take body size and adiposity into account.

\section{Additional file}

Additional file 1: Four supplementary tables. Table S1. Allele

frequencies and distributions of selected single-nucleotide polymorphisms (SNPs) in CYP19A1: The Norwegian EBBA-I study. Table S2. Population frequencies of single-nucleotide polymorphisms (SNPs) in selected

single-nucleotide polymorphisms in CYP19A1. Table S3. Associations between each of eight selected single-nucleotide polymorphisms (SNPs) in the CYP19A1 region and mammographic density (total breast area, absolute density, percent density and nondense breast areas). Table S4. Associations between each of eight selected single-nucleotide polymorphisms (SNPS) in the CYP19A1 region and estradiol.

\section{Abbreviations}

BMI: Body mass index; Cl: Confidence interval; CV: Coefficient of variation; EBBA-I: Norwegian Energy Balance and Breast cancer Aspects I study; ER: Oestrogen receptor; HGF: Hepatocyte growth factor; kb: Kilobase; HDL-C: High-density lipoprotein cholesterol; OR: Odds ratio; LDL-C: Low-density lipoprotein cholesterol; ROl: Region of interest; SNP: Single nucleotide polymorphism; UNN: University Hospital of North Norway, Tromsø.

\section{Competing interests}

The authors declare that they have no competing interests.

\section{Authors' contributions}

IT and ASF conceived of and designed the study and collected the clinical data. PTE carried out the radioimmunoassay and measured salivary hormone levels. GU digitized and measured the mammographic density data. KWM and $A M$ performed the single-nucleotide polymorphism analysis. VGF, HF, TL, TE, TW, Al, EAW and JCC performed statistical analyses. VGF, ASF, AM, HF, GU, Al, TL, PTE, EAW, TE, TW, KWM, JCC and IT interpreted the results. VGF drafted the manuscript in cooperation with IT. All authors contributed to critical revision of the manuscript, editing of the final version of the manuscript and agree to be accountable for the accuracy and integrity of the work. All authors read and approved the final manuscript.

\section{Acknowledgements}

We acknowledge each woman who participated in the EBBA-I study and give special thanks to Gunn Kristin Knudsen, Heidi Jakobsen, Anna-Kirsti Kvitnes and Sissel Andersen for professional assistance, and to the Clinical Research Department, University Hospital of North Norway, for providing the skilled and always professional setting. Funding for this study was provided by the Norwegian Foundation for Health and Rehabilitation grants 59010-2000/2001/2002 Norwegian Cancer Society grants 05087 and TP 49 258, Aakre Foundation grants 5695-2000 and 5754-2002 and South-East Norwegian Health Authority grant 2012064.

\section{Author details}

'The Cancer Centre, Oslo University Hospital, Oslo N-0424, Norway. ${ }^{2}$ Department of Community Medicine, Faculty of Health Sciences, UiT, The Arctic University of Norway, Tromsø N-9037, Norway. ${ }^{3}$ Fred Hutchinson Cancer Research Center, Public Health Sciences Division, Seattle, WA 98109-1024, USA. ${ }^{4}$ Cancer Registry of Norway, PO Box 5313Majorstuen, Oslo N-0304, Norway. ${ }^{5}$ Faculty of Health Sciences, UiT, The Arctic University of Norway, Tromsø N-9037, Norway. ${ }^{6}$ Department of Anthropology, Harvard University, Cambridge, MA 02138, USA. 'Department of Chemistry, Norwegian University of Life Sciences, Biotechnology and Food Science, Aas $\mathrm{N}-1432$, Norway. ${ }^{8}$ Unit of Genetic Epidemiology, Division of Cancer Epidemiology, Deutches Krebsforschungszentrum, 69120 Heidelberg, Germany.

Received: 24 June 2014 Accepted: 8 December 2014

Published online: 19 December 2014

\section{References}

1. Folkerd E, Dowsett M: Sex hormones and breast cancer risk and prognosis. Breast 2013, 22:S38-S43. doi:10.1016/j.breast.2013.07.007.

2. Key T, Appleby P, Barnes I, Reeves G: Endogenous sex hormones and breast cancer in postmenopausal women: reanalysis of nine prospective studies. J Natl Cancer Inst 2002, 94:606-616.

3. Endogenous Hormones and Breast Cancer Collaborative Group, Key TJ, Appleby PN, Reeves GK, Travis RC, Alberg AJ, Barricarte A, Berrino F, Krogh V, Sieri S, Brinton LA, Dorgan JF, Dossus L, Dowsett M, Eliassen AH, Fortner RT, Hankinson SE, Helzlsouer KJ, Hoffman-Bolton J, Comstock GW, Kaaks R, Kahle LL, Muti P, Overvad K, Peeters PH, Riboli E, Rinaldi S, Rollison DE, Stanczyk FZ, Trichopoulos D, et al: Sex hormones and risk of breast cancer in premenopausal women: a collaborative reanalysis of individual participant data from seven prospective studies. Lancet Oncol 2013, 14:1009-1019. doi:10.1016/S1470-2045(13)70301-2. 
4. Haynes BP, Viale G, Galimberti V, Rotmensz N, Gibelli B, A'Hern R, Smith IE, Dowsett M: Expression of key oestrogen-regulated genes differs substantially across the menstrual cycle in oestrogen receptor-positive primary breast cancer. Breast Cancer Res Treat 2013, 138:157-165. doi:10.1007/s10549-013-2426-0.

5. Simpson ER, Mahendroo MS, Means GD, Kilgore MW, Hinshelwood MM, Graham-Lorence S, Amarneh B, Ito Y, Fisher CR, Michael MD, Mendelson CR, Bulun SE: Aromatase cytochrome P450, the enzyme responsible for estrogen biosynthesis. Endocr Rev 1994, 15:342-355.

6. Bulun SE, Sebastian S, Takayama K, Suzuki T, Sasano H, Shozu M: The human CYP19 (aromatase P450) gene: update on physiologic roles and genomic organization of promoters. J Steroid Biochem Mol Biol 2003, 86:219-224.

7. Morris PG, Hudis CA, Giri D, Morrow M, Falcone DJ, Zhou XK, Du B, Brogi E, Crawford CB, Kopelovich L, Subbaramaiah K, Dannenberg AJ: Inflammation and increased aromatase expression occur in the breast tissue of obese women with breast cancer. Cancer Prev Res (Phila) 2011, 4:1021-1029.

8. Zhao Y, Nichols JE, Valdez R, Mendelson CR, Simpson ER: Tumor necrosis factor-a stimulates aromatase gene expression in human adipose stromal cells through use of an activating protein-1 binding site upstream of promoter 1.4. Mol Endocrinol 1996, 10:1350-1357.

9. Subbaramaiah K, Howe LR, Bhardwaj P, Du B, Gravaghi C, Yantiss RK, Zhou XK, Blaho VA, Hla T, Yang P, Kopelovich L, Hudis CA, Dannenberg AJ: Obesity is associated with inflammation and elevated aromatase expression in the mouse mammary gland. Cancer Prev Res (Phila) 2011, 4:329-346.

10. Haiman CA, Dossus L, Setiawan WW, Stram DO, Dunning AM, Thomas G, Thun MJ, Albanes D, Altshuler D, Ardanaz E, Boeing H, Buring J, Burtt N, Calle EE, Chanock S, Clavel-Chapelon F, Colditz GA, Cox DG, Feigelson HS, Hankinson SE, Hayes RB, Henderson BE, Hirschhorn JN, Hoover R, Hunter DJ, Kaaks R, Kolonel LN, Le Marchand L, Lenner P, Lund E, et al: Genetic variation at the CYP19A1 locus predicts circulating estrogen levels but not breast cancer risk in postmenopausal women. Cancer Res 2007, 67:1893-1897. doi:10.1158/0008-5472.can-06-4123.

11. Tamimi RM, Hankinson SE, Colditz GA, Byrne C: Endogenous sex hormone levels and mammographic density among postmenopausal women. Cancer Epidemiol Biomarkers Prev 2005, 14:2641-2647. doi:10.1158/10559965.epi-05-0558.

12. Becker S, Kaaks R: Exogenous and endogenous hormones, mammographic density and breast cancer risk: can mammographic density be considered an intermediate marker of risk? Recent Results Cancer Res 2009, 181:135-157.

13. Johansson H, Gandini S, Bonanni B, Mariette F, Guerrieri-Gonzaga A, Serrano D, Cassano E, Ramazzotto F, Baglietto L, Sandri MT, Decensi A: Relationships between circulating hormone levels, mammographic percent density and breast cancer risk factors in postmenopausal women. Breast Cancer Res Treat 2008, 108:57-67.

14. Walker K, Fletcher O, Johnson N, Coupland B, McCormack VA, Folkerd E, Gibson L, Hillier SG, Holly JM, Moss S, Dowsett M, Peto J, dos Santos Silva I: Premenopausal mammographic density in relation to cyclic variations in endogenous sex hormone levels, prolactin, and insulin-like growth factors. Cancer Res 2009, 69:6490-6499.

15. Greendale GA, Palla SL, Ursin G, Laughlin GA, Crandall C, Pike MC, Reboussin BA: The association of endogenous sex steroids and sex steroid binding proteins with mammographic density: results from the Postmenopausal Estrogen/ Progestin Interventions Mammographic Density Study. Am J Epidemiol 2005 162:826-834. doi:10.1093/aje/kwi286.

16. McCormack VA, dos Santos SI: Breast density and parenchymal patterns as markers of breast cancer risk: a meta-analysis. Cancer Epidemiol Biomarkers Prev 2006, 15:1159-1169.

17. Pettersson A, Graff RE, Ursin G, dos Santos Silva I, McCormack V, Baglietto L, et al. Mammographic density phenotypes and risk of breast cancer: a meta-analysis. J Natl Cancer Inst. in press. doi: 10.1093/jnci/dju078.

18. Ursin G, Lillie EO, Lee E, Cockburn M, Schork NJ, Cozen W, Parisky YR, Hamilton AS, Astrahan MA, Mack T: The relative importance of genetics and environment on mammographic density. Cancer Epidemiol Biomarkers Prev 2009, 18:102-112.

19. Boyd NF, Martin $\sqcup$, Rommens JM, Paterson AD, Minkin S, Yaffe MJ, Stone J, Hopper JL: Mammographic density: a heritable risk factor for breast cancer Methods Mol Biol 2009, 472:343-360. doi:10.1007/978-1-60327-492-0_15.

20. Lindström S, Vachon CM, Li J, Varghese J, Thompson D, Warren R, Brown J, Leyland J, Audley T, Wareham NJ, Loos RJ, Paterson AD, Rommens J,
Waggott D, Martin U, Scott CG, Pankratz VS, Hankinson SE, Hazra A, Hunter DJ, Hopper JL, Southey MC, Chanock SJ, dos Santos Silva I, Liu J, Eriksson L, Couch FJ, Stone J, Apicella C, Czene K, et al: Common variants in ZNF365 are associated with both mammographic density and breast cancer risk. Nat Genet 2011, 43:185-187. doi:10.1038/ng.760.

21. Vachon CM, Kuni CC, Anderson K, Anderson VE, Sellers TA: Association of mammographically defined percent breast density with epidemiologic risk factors for breast cancer (United States). Cancer Causes Control 2000, 11:653-662.

22. Ursin G, Longnecker MP, Haile RW, Greenland S: A meta-analysis of body mass index and risk of premenopausal breast cancer. Epidemiology 1995 6:137-141.

23. Suzuki R, Iwasaki M, Inoue M, Sasazuki S, Sawada N, Yamaji T, Shimazu T, Tsugane S, the Japan Public Health Center-based Prospective Study Group: Body weight at age 20 years, subsequent weight change and breast cancer risk defined by estrogen and progesterone receptor status-the Japan public health center-based prospective study. Int J Cancer 2011, 129:1214-1224. doi:10.1002/ijc.25744.

24. Suzuki S, Kojima M, Tokudome S, Mori M, Sakauchi F, Wakai K, Fujino Y, Lin Y, Kikuchi S, Tamakoshi K, Tamakoshi A: Obesity/weight gain and breast cancer risk: findings from the Japan collaborative cohort study for the evaluation of cancer risk. J Epidemio/ 2013, 23:139-145.

25. Michels KB, Terry KL, Eliassen AH, Hankinson SE, Willett WC: Adult weight change and incidence of premenopausal breast cancer. Int J Cancer 2012, 130:902-909. doi:10.1002/ijc.26069.

26. Harris HR, Willett WC, Terry KL, Michels KB: Body fat distribution and risk of premenopausal breast cancer in the Nurses' Health Study II. J Natl Cancer Inst 2011, 103:273-278. doi:10.1093/jnci/djq500.

27. Lahmann PH, Hoffmann K, Allen N, van Gils CH, Khaw KT, Tehard B, Berrino F, Tjønneland A, Bigaard J, Olsen A, Overvad K, Clavel-Chapelon F, Nagel G, Boeing H, Trichopoulos D, Economou G, Bellos G, Palli D, Tumino R, Panico S, Sacerdote C, Krogh V, Peeters PH, Bueno-de-Mesquita HB, Lund E, Ardanaz E, Amiano P, Pera G, Quirós JR, Martínez C, et al: Body size and breast cancer risk: findings from the European Prospective Investigation into Cancer and Nutrition (EPIC). Int J Cancer 2004, 111:762-771. doi:10.1002/ijc.20315.

28. Suzuki R, Orsini N, Saji S, Key TJ, Wolk A: Body weight and incidence of breast cancer defined by estrogen and progesterone receptor status-a meta-analysis. Int J Cancer 2009, 124:698-712. doi:10.1002/ijc.23943.

29. Emaus A, Espetvedt S, Veierød MB, Ballard-Barbash R, Furberg AS, Ellison PT, Jasienska G, Hjartåker A, Thune I: 17- $\beta$-estradiol in relation to age at menarche and adult obesity in premenopausal women. Hum Reprod 2008, 23:919-927.

30. Furberg AS, Jasienska G, Bjurstam N, Torjesen PA, Emaus A, Lipson SF, Ellison PT, Thune I: Metabolic and hormonal profiles: HDL cholesterol as a plausible biomarker of breast cancer risk. The Norwegian EBBA Study. Cancer Epidemiol Biomarkers Prev 2005, 14:33-40.

31. Lillegaard IT, Andersen LF: Validation of a pre-coded food diary with energy expenditure, comparison of under-reporters v. acceptable reporters. Br J Nutr 2005, 94:998-1003.

32. Lipson SF, Ellison PT: Development of protocols for the application of salivary steroid analysis to field conditions. Am J Hum Biol 1989, 1:249-255. doi:10.1002/ajhb.1310010304

33. Ellison PT, Lipson SF: Salivary estradiol-a viable alternative? Fertil Steril 1999, 72:951-952.

34. Lipson SF, Ellison PT: Comparison of salivary steroid profiles in naturally occurring conception and non-conception cycles. Hum Reprod 1996, 11:2090-2096.

35. Ursin G, Astrahan MA, Salane M, Parisky YR, Pearce JG, Daniels JR, Pike MC, Spicer DV: The detection of changes in mammographic densities. Cancer Epidemiol Biomarkers Prev 1998, 7:43-47.

36. Ursin G, Ma H, Wu AH, Bernstein L, Salane M, Parisky YR, Astrahan M, Siozon CC, Pike MC: Mammographic density and breast cancer in three ethnic groups. Cancer Epidemiol Biomarkers Prev 2003, 12:332-338.

37. Passarelli MN, Phipps Al, Potter JD, Makar KW, Coghill AE, Wernli KJ, White E, Chan AT, Hutter CM, Peters U, Newcomb PA: Common single-nucleotide polymorphisms in the estrogen receptor $\beta$ promoter are associated with colorectal cancer survival in postmenopausal women. Cancer Res 2013 73:767-775. doi:10.1158/0008-5472.can-12-2484.

38. Carlson CS, Eberle MA, Rieder MJ, Yi Q, Kruglyak L, Nickerson DA: Selecting a maximally informative set of single-nucleotide polymorphisms for 
association analyses using linkage disequilibrium. Am J Hum Genet 2004, 74:106-120. doi:10.1086/381000.

39. Thorisson GA, Smith AV, Krishnan L, Stein LD: The International HapMap Project Web site. Genome Res 2005, 15:1592-1593. doi:10.1101/gr.4413105.

40. Rice MS, Biessy C, Lajous M, Bertrand KA, Tamimi RM, Torres-Mejía G, LópezRidaura R, Romieu I: Metabolic syndrome and mammographic density in Mexican women. Cancer Prev Res (Phila) 2013, 6:701-710. doi:10.1158/19406207.CAPR-12-0475.

41. Milne RL, Burwinkel B, Michailidou K, Arias-Perez Jl, Zamora MP, MenéndezRodríguez P, Hardisson D, Mendiola M, González-Neira A, Pita G, Alonso MR, Dennis J, Wang Q, Bolla MK, Swerdlow A, Ashworth A, Orr N, Schoemaker M, Ko YD, Brauch H, Hamann U, Network GENICA, Andrulis IL, Knight JA, Glendon G, Tchatchou S, kConFab Investigators, Australian Ovarian Cancer Study Group, Matsuo K, Ito H, et al: Common non-synonymous SNPs associated with breast cancer susceptibility: findings from the Breast Cancer Association Consortium. Hum Mol Genet 2014, 23:6096-6111. doi:10.1093/hmg/ddu311.

42. Robbez-Masson L, Bödör C, Jones JL, Hurst HC, Fitzgibbon J, Hart IR, Grose RP: Functional analysis of a breast cancer-associated FGFR2 single nucleotide polymorphism using zinc finger mediated genome editing. PLoS One 2013, 8:e78839. doi:10.1371/journal.pone.0078839.

43. Cai H, Shu XO, Egan KM, Cai Q, Long JR, Gao YT, Zheng W: Association of genetic polymorphisms in CYP19A1 and blood levels of sex hormones among postmenopausal Chinese women. Pharmacogenet Genomics 2008, 18:657-664. doi:10.1097/FPC.0b013e3282fe3326.

44. Wang L, Ellsworth KA, Moon I, Pelleymounter LL, Eckloff BW, Martin YN, Fridley BL, Jenkins GD, Batzler A, Suman VJ, Ravi S, Dixon JM, Miller WR, Wieben ED, Buzdar A, Weinshilboum RM, Ingle JN: Functional genetic polymorphisms in the aromatase gene CYP19 vary the response of breast cancer patients to neoadjuvant therapy with aromatase inhibitors. Cancer Res 2010, 70:319-328. doi:10.1158/0008-5472.can-09-3224.

45. Li J, Eriksson L, Humphreys K, Czene K, Liu J, Tamimi RM, Lindström S, Hunter DJ, Vachon CM, Couch FJ, Scott CG, Lagiou P, Hall P: Genetic variation in the estrogen metabolic pathway and mammographic density as an intermediate phenotype of breast cancer. Breast Cancer Res 2010, 12:R19. doi:10.1186/bcr2488.

46. Ozhand A, Lee E, Wu AH, Ellingjord-Dale M, Akslen LA, McKean-Cowdin R, Ursin G: Variation in inflammatory cytokine/growth-factor genes and mammographic density in premenopausal women aged 50-55. PLOS One 2013, 8:e65313.

47. Kristensen VN, Andersen TI, Lindblom A, Erikstein B, Magnus P, Børresen-Dale AL: A rare CYP19 (aromatase) variant may increase the risk of breast cancer. Pharmacogenetics 1998, 8:43-48.

48. Low YL, Li Y, Humphreys K, Thalamuthu A, Li Y, Darabi H, Wedrén S, Bonnard C, Czene K, lles MM, Heikkinen T, Aittomäki K, Blomqvist C, Nevanlinna H, Hall P, Liu ET, Liu J: Multi-variant pathway association analysis reveals the importance of genetic determinants of estrogen metabolism in breast and endometrial cancer susceptibility. PLoS Genet 2010, 6:e1001012. doi:10.1371/journal.pgen.1001012.

49. Ma X, Qi X, Chen C, Lin H, Xiong H, Li Y, Jiang J: Association between CYP19 polymorphisms and breast cancer risk: results from 10,592 cases and 11,720 controls. Breast Cancer Res Treat 2010, 122:495-501.

50. Talbott KE, Gammon MD, Kibriya MG, Chen Y, Teitelbaum SL, Long CM, Gurvich I, Santella RM, Ahsan H: A CYP19 (aromatase) polymorphism is associated with increased premenopausal breast cancer risk. Breast Cancer Res Treat 2008, 111:481-487. doi:10.1007/s10549-007-9794-2.

51. Zins K, Mogg M, Schneeberger C, Abraham D, Schreiber M: Analysis of the rs10046 Polymorphism of Aromatase (CYP19) in Premenopausal Onset of Human Breast Cancer. Int J Mol Sci 2014, 15:712-724. doi:10.3390/ ijms15010712.

52. Liedtke S, Schmidt ME, Vrieling A, Lukanova A, Becker S, Kaaks R, Zaineddin AK, Buck K, Benner A, Chang-Claude J, Steindorf K: Postmenopausal sex hormones in relation to body fat distribution. Obesity (Silver Spring) 2012, 20:1088-1095. doi:10.1038/oby.2011.383.

53. Williams NI, Reed JL, Leidy HJ, Legro RS, De Souza MJ: Estrogen and progesterone exposure is reduced in response to energy deficiency in women aged 25-40 years. Hum Reprod 2010, 25:2328-2339. doi:10.1093/ humrep/deq172.

54. Campbell KL, Foster-Schubert KE, Alfano CM, Wang CC, Wang CY, Duggan CR, Mason C, Imayama I, Kong A, Xiao L, Bain CE, Blackburn GL, Stanczyk FZ, McTiernan A: Reduced-calorie dietary weight loss, exercise, and sex hormones in postmenopausal women: randomized controlled trial. J Clin Oncol 2012, 30:2314-2326.

55. Iversen A, Thune I, McTiernan A, Makar KW, Wilsgaard T, Ellison PT, Jasienska G, Flote V, Poole EM, Furberg AS: Genetic polymorphism CYP17 rs2486758 and metabolic risk factors predict daily salivary $17 \beta$-estradiol concentration in healthy premenopausal Norwegian women. The EBBA-I study. J Clin Endocrinol Metab 2012, 97:E852-E857.

56. Yaghjyan L, Colditz GA, Rosner B, Tamimi RM: Mammographic breast density and subsequent risk of breast cancer in postmenopausal women according to the time since the mammogram. Cancer Epidemiol Biomarkers Prev 2013, 22:1110-1117.

57. van Gils $\mathrm{CH}$, Hendriks JH, Otten JD, Holland R, Verbeek AL: Parity and mammographic breast density in relation to breast cancer risk: indication of interaction. Eur $J$ Cancer Prev 2000, 9:105-111.

58. Lin JH, Gunter MJ, Manson JE, Rexrode KM, Cook NR, Kraft P, Cochrane BB, Chlebowski RT, Ho GY, Zhang SM: The aromatase gene (CYP19A1) variants and circulating hepatocyte growth factor in postmenopausal women. PLoS One 2012, 7:e42079. doi:10.1371/journal.pone.0042079.

59. Casbas-Hernandez P, D'Arcy M, Roman-Perez E, Brauer HA, McNaughton K, Miller SM, Chhetri RK, Oldenburg AL, Fleming JM, Amos KD, Makowski L, Troester MA: Role of HGF in epithelial-stromal cell interactions during progression from benign breast disease to ductal carcinoma in situ. Breast Cancer Res 2013, 15:R82. doi:10.1186/bcr3476.

60. Schoemaker MJ, Folkerd EJ, Jones ME, Rae M, Allen S, Ashworth A, Dowsett $M$, Swerdlow AJ: Combined effects of endogenous sex hormone levels and mammographic density on postmenopausal breast cancer risk: results from the Breakthrough Generations Study. Br J Cancer 2014, 110:1898-1907. doi:10.1038/bjc.2014.64.

61. Tworoger SS, Zhang X, Eliassen AH, Qian J, Colditz GA, Willett WC, Rosner $B A$, Kraft $P$, Hankinson SE: Inclusion of endogenous hormone levels in risk prediction models of postmenopausal breast cancer. J Clin Oncol 2014, 32:3111-3117. doi:10.1200/jco.2014.56.1068.

62. Holst JP, Soldin OP, Guo T, Soldin SJ: Steroid hormones: relevance and measurement in the clinical laboratory. Clin Lab Med 2004, 24:105-118. doi:10.1016/j.cll.2004.01.004

63. Furberg AS, Veierød MB, Wilsgaard T, Bernstein L, Thune I: Serum highdensity lipoprotein cholesterol, metabolic profile, and breast cancer risk. J Natl Cancer Inst 2004, 96:1152-1160.

\section{Submit your next manuscript to BioMed Central and take full advantage of:}

- Convenient online submission

- Thorough peer review

- No space constraints or color figure charges

- Immediate publication on acceptance

- Inclusion in PubMed, CAS, Scopus and Google Scholar

- Research which is freely available for redistribution

Submit your manuscript at www.biomedcentral.com/submit
C) Biomed Central 